\title{
Atividade Antibacteriana do Extrato Hidroalcoólico da Casca do Jucá (Libidibia Ferrea (Mart. Ex Tul.) L.P.Queiroz), em Leite Caprino Mastitíco
}

Weslley de Souza Paiva (II), Francisco Ernesto de Souza Neto (II), Maria Gilnara Lima Bandeira (I), Maria Rociene Abrantes (II), Anabelle Camarotti de Lima Batista (II), Monique Ellen Torres da

Silva (I), Anakláudia Sombra Santos (I), Monique de Oliveira (I) IFCE - Instituto Federal do Ceará (Rua Estevão Remígio, 1145 - Centro - Limoeiro do Norte CE), (II) UFERSA - Universidade Federal Rural do Semi Árido (Av. Francisco mota, Mossoró $\mathrm{RN})$

\section{Resumo}

A caprinocultura leiteira é de grande importância para a economia da região nordeste. $\mathrm{O}$ manejo inadequado das cabras provoca uma série de doenças que prejudicam a produção, dentre elas a mastite, que é a inflamação das glândulas mamárias, infecção causada por um ampla variedade de micro-organismos. O uso indiscriminado de antibióticos no tratamento de mastite ocasiona a seleção da microbiota resistente, dificultando o tratamento da doença. Esse trabalho tem como objetivo, testar a atividade antimicrobiana do extrato hidroalcoólico da casca de Jucá (Libidibia ferrea (Mart. ex Tul.) L.P.Queiroz) em diferentes concentrações contra micro-organismos causadores de mastite em caprinos. Foram isoladas 18 estirpes bacterianas, isoladas a partir de leite mastitíco e foram identificados como sendo do gênero Staphylococcus, através de técnicas de identificação, como coloração de gram, catalase e coagulase, as quais todas tiveram resultados positivos. Essas estirpes foram crescidas em meio ágar sangue, as quais foram transferidas para caldo BHI e após o crescimento, foi feito o teste antimicrobiano pela técnica de difusão em discos, usando os antibióticos conhecidos como beta-lactâmicos: Ampicilina, Cefalexina, Gentamicina, Penicilina G e Oxacilina. Foram testadas três concentrações

\footnotetext{
Referência:

Weslley de Souza Paiva, Francisco Ernesto de Souza Neto, Maria Gilnara Lima Bandeira, Maria Rociene Abrantes, Anabelle Camarotti de Lima Batista, Monique Ellen Torres da Silva, Anakláudia Sombra Santos, Monique de Oliveira. Atividade Antibacteriana do Extrato Hidroalcoólico da Casca do Jucá (Libidibia Ferrea (Mart. Ex Tul.) L.P.Queiroz), em Leite Caprino Mastitíco. In: Anais do 12 Congresso Latinoamericano de Microbiologia e Higiene de Alimentos MICROAL 2014 [= Blucher Food Science Proceedings, num.1, vol.1]. São Paulo: Editora Blucher, 2014. DOI 10.5151/foodsci-microal-290
} 
de extrato de L. ferrea (extrato bruto, extrato $70 \%(\mathrm{v} / \mathrm{v})$ e extrato $50 \%(\mathrm{v} / \mathrm{v})$. Os resultados mostram que os micro-organismos isolados apresentam alta resistência a ampicilina, penicilina $\mathrm{G}$ e oxacilina, apresentando resistência de 88,83 e $77 \%$ respectivamente. O extrato bruto apresentou uma eficiência de $61,1 \%$ na inibição dos micro-organismos em teste. Os resultados mostraram que o extrato hidroalcoólico bruto da casca de L. ferrea tem potencial como antimicrobiano natural contra micro-organismos causadores de mastite caprina.

Palavras-Chave: Mastite, Libidibia ferrea, Resistência Agência de Fomento: 